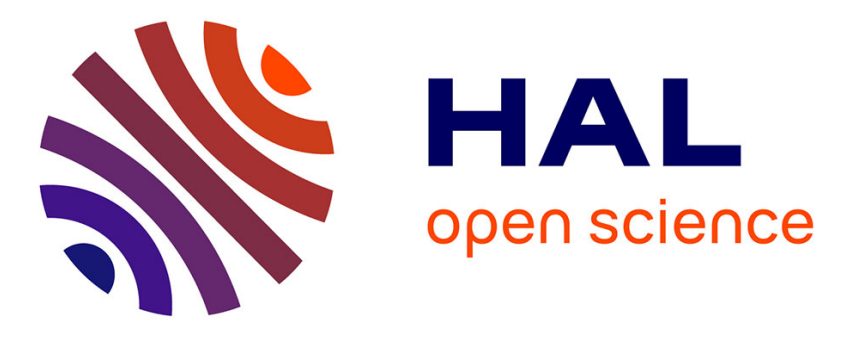

\title{
Mismothering and remedying the mother-young relationship in stabled dromedary camels
}

\author{
Imen Hammadi, Mohamed Chniter, Marwa Brahmi, Moufida Atigui, \\ Mohamed Dhia Bouzaida, Mouldi-Mabrouk Seddik, Raymond Nowak, \\ Gustavo Adolfo María, Mohamed Hammadi
}

\section{To cite this version:}

Imen Hammadi, Mohamed Chniter, Marwa Brahmi, Moufida Atigui, Mohamed Dhia Bouzaida, et al.. Mismothering and remedying the mother-young relationship in stabled dromedary camels. Applied Animal Behaviour Science, 2021, 243, pp.1-9. 10.1016/j.applanim.2021.105424 . hal-03382836

\section{HAL Id: hal-03382836 https://hal.science/hal-03382836}

Submitted on 20 Oct 2021

HAL is a multi-disciplinary open access archive for the deposit and dissemination of scientific research documents, whether they are published or not. The documents may come from teaching and research institutions in France or abroad, or from public or private research centers.
L'archive ouverte pluridisciplinaire HAL, est destinée au dépôt et à la diffusion de documents scientifiques de niveau recherche, publiés ou non, émanant des établissements d'enseignement et de recherche français ou étrangers, des laboratoires publics ou privés. 
Mismothering and remedying the mother-young relationship in stabled

\section{dromedary camels}

Imen Hammadi a,b , Mohamed Chniter a,c, Marwa Brahmi a,d, Moufida Atigui e,

Mohamed Dhia Bouzaida ${ }^{\mathrm{f}}$, Mouldi-Mabrouk Seddik a, Raymond Nowak g,

\section{Gustavo Adolfo María ${ }^{\mathrm{f}}$, Mohamed Hammadi a,h}

a : Institut des Régions Arides, 4100 Médenine, IRESA, Université de Gabès, Tunisie

b: Faculté des Sciences de Gabès, Université de Gabès, Cité Erriadh 6072 Gabès,

Tunisie

c: Institut National Agronomique de Tunisie, 43 Av. Charles Nicolle 1082 Tunis,

Tunisie

d : Institut Supérieur Agronomique de Chott-Mériem, 4042 Chott Mériem, Sousse,

Tunisie

e : Ecole Supérieure d'Agriculture de Mateur, Université de Carthage, 7030 Mateur,

Tunisie

f: Facultad de Veterinaria de Zaragoza, Calle Miguel Servet, 177, 50013 Zaragoza

España

g: Physiologie de la Reproduction et des Comportements, PRC, INRAE, CNRS,

IFCE, Université de Tours, 37380 Nouzilly, France

h: Ecole Doctorale SIS, Université de Gabès Cité Erriadh 6072 Gabès, Tunisie

* Corresponding author

E-mail address: imen.mohamed1290@gmail.com (I. Hammadi) 


\section{Introduction}

Camel husbandry is currently evolving from a pastoral towards to an intensive system, due to a selection process for the use of this species in meat and milk production (Faye, 2016). Captivity in intensive systems affects locomotion and social activities, limits the expression of various behavioural needs and causes the expression of abnormal behaviours in male camels (Padalino et al., 2014); indoor living conditions could also affect female behaviour especially around parturition. Giving birth and providing maternal care during the early postpartum period are an essential and critical part of animal breeding management. Ruminants usually isolate from the herd when ready to give birth, an adaptive process that allow the females to give birth in a calm environment away from threats and social disturbances. In normal parturition, the mother turns toward her neonate soon after giving birth and interacts closely with it. Normal maternal responsiveness is characterized by sniffing, nursing and vocalizing activities (sheep and goats: Poindron et al., 2007; cattle: Rørvang et al., 2018, camels: Hammadi et al., 2021). Licking the neonate is also common except in camels (Hammadi et al., 2021). Mutual mother-young recognition develops at an early stage and ensures selective suckling and care of the newborn; this satisfies basic requirements such as food, warmth, and protection for its welfare and ensures that the mother does not misspend time and energy in alien young. Consequently, it is acknowledged that the survival of the young ruminant relies, by in large, on appropriate care and selective mother-young bonding (Nowak et al., 2000; Dwyer and Lawrence, 2005). 
Studies in cattle have shown that intensive management systems, involving restricted space and high stocking densities, increase the risk of behavioural disturbances and mismothering during the peripartum period, with failure to provide adequate amount of colostrum to the neonate (Rørvang et al., 2018). Should a newborn calf be abandoned by its mother, even temporarily, nutritional and behavioural needs are not met, and its survival is at risk (Vogels et al., 2013). While inadequate maternal care and rejection behaviours have been well investigated in cattle, sheep, goats, and mares (Poindron et al., 2007; Żurek and Danek, 2012; Kohari and Takakura, 2017), this aspect has never, to date, been investigated in dromedary camels. Research is needed to understand camel postpartum behaviour and the reasons leading to the potential rejection of newborns. Should this happen, it is important to develop practical solution to remedy mismothering. Like other ruminants, newborn camels are agammaglobulinemic, so colostrum is the main source of food and early protective antibodies (Salhi et al., 2014). Any delay in colostrum ingestion due to inadequate maternal care may be fatal. One potential solution is to confine rejecting mothers in a pen and force them to maintain proximity with their offspring repetitively. This has proven being efficient in sheep for reestablishing proper mother-young relationships (Alexander and Bradley, 1985). Other procedures to remedy altered maternal behaviour in ruminants have been described. In a study by Levey et al. (1992), primiparous ewes prevented from becoming maternal at birth using an epidural anaesthetic block, oxytocin treatment was also effective in inducing full maternal responsiveness. In Tunisian traditional system, the camel breeders restrain the mismothering dam with her neonate far from the rest of the herd. Then, they obstruct the vulva after putting small stones into the vagina and partially block the normal respiration. Even if she-camel accepts her 
newborn after 3 to 4 hours, these practices are contrasts with ethics and animal welfare. Dioli (2012) described rather unusual technique by the Somali and neighboring ethnic groups to treat camel's newborn rejection. This technique included isolating the newly partum camel and her calf than mimicking the behaviour and sound of predators usually at sunset or early night. Soon after she camel reacts to protect the calf, the impersonate retreats. Few nights with this deceit are sufficient to establish maternal-young bond (Dioli, 2012).

Alterations in maternal responsiveness are triggered by stress, because the process of parturition itself is stressful or because the environment does not comply with the behavioural needs of the individual. Behavioural and physiological responses observed in disturbed animals reflect their emotional reactivity (Deiss et al., 2009). Cortisol, which is considered as an indicator of stress, is also used to predict the time of parturition in female dromedary camels (Abd-El-Rahman et al., 2017).

Fœtal cortisol and thyroid hormones play an important role in the maturation and development of the young (Liggins, 1994). The decrease of the prepartum cortisol surge in sheep for example reveals a dual mechanism. Firstly, late pregnancy is associated with a rise in cortisol levels being the highest in the last 1-2 days of uterine life, as it is the activation of the hypothalamic-pituitary-adrenal function that is responsible for the birth process (Challis and Brooks, 1989). Secondly, the decline in cortisol concurs with periods during which thyroid hormones increase as thermal efficiency improves and rectal temperature stabilizes (Chniter et al., 2016).

During parturition cortisol levels increase from basal levels at around $21.9 \pm$ $1.0 \mathrm{ng} / \mathrm{ml}$ to more than $121.6 \pm 5.4 \mathrm{ng} / \mathrm{ml}$ (Mohamed, 2006). This suggests that 
cortisol may also be used as an indicator of postpartum stress and could be linked to the expression of proper or inadequate maternal responsiveness.

The purpose of this study was twofold. First, we described mismothering behaviours in a herd of stabled dromedary camels, assessed its importance, and identified the causes of calf rejection. Plasma cortisol was also used as a physiological index that would relate to mismothering. Second, we designed a suitable method to try and solve this issue, based on restrain, forced body contact while bottle-feeding the neonate, and food-reward when the mother displayed signs of acceptance.

\section{Material and methods}

\subsection{Animals and housing}

The study was conducted at the experimental station of the "Institut des Régions Arides de Médenine", located in southeastern Tunisia $\left(33^{\circ} 30^{\prime} \mathrm{N}, 10^{\circ} 40^{\prime}\right.$ E), with a typical Mediterranean climate. The work was conducted during two consecutive calving seasons (1 ${ }^{\text {st }}$ season: November 2016-March 2017 and $2^{\text {nd }}$ season: November 2017- April 2018) on respectively 36 (10 primiparas and 26 multiparas) pregnant dromedary females (weighing $440.0 \pm 38.0 \mathrm{~kg}$, aged $12.7 \pm 5.7$ years) and 9 (3 primiparas and 6 multiparas) pregnant dromedary females (weighing $446.0 \pm 73.0 \mathrm{~kg}$, aged $14.0 \pm 6.2$ years). During these two seasons, a total of 6 shecamels showed signs of calf rejection (mother moving more than $2 \mathrm{~m}$ away from her newborn just after giving birth) and were assigned to the group of mismothering dams (rejecting group). Whenever a rejection case was recorded, the first following calving with a successful mother-young relationship was also recorded to serve as a control (accepting group). The two mothers group had the same housing conditions. 
Subsequently, after the first hour postpartum, the mothers accepting their neonates were moved to a maternity enclosure $\left(15 \mathrm{~m}^{2}\right)$, while those rejecting their calves were moved to a confinement enclosure $\left(15 \mathrm{~m}^{2}\right)$ located $200 \mathrm{~m}$ from the rest of the herd, to remediate the dam-young bond. The calving pen, feeding and management procedures of the same experimental herd were described previously by Hammadi et al. (2021).

\subsection{Behavioural measurements}

Digital infrared video cameras (DAHUA - HAC-HDW1220M) were mounted above the calving pen and used to determine calving behaviours from the appearance of the amniotic sac to the total expulsion of the calf. A qualified person was present during the parturition process to detect and describe the incidence of potential complication (dystocia, uterine prolapse, retained placenta, inappropriate maternal behaviour...) and/or disturbance occurred (presence of alien calves...). Maternal behaviours during the $1^{\text {st }}$ hour post-calving (sniffing duration and number of low and high-pitched grunts) were measured in the accepting and rejecting groups using a camcorder (Sony ${ }^{\circledR} \mathrm{X60}$ ). During the first three days postpartum, maternal behaviour was videotaped for the rejecting group in the confinement enclosure over a 30 min period after $1 \mathrm{~h}, 6 \mathrm{~h}, 12 \mathrm{~h}, 24 \mathrm{~h}, 48 \mathrm{~h}, 72 \mathrm{~h}$ of confinement, however at $7 \mathrm{~d}$ postpartum, maternal behaviour was recorded for accepting and rejecting groups. An ethogram was defined to code and measure behaviour traits using the focal-animal sampling method (Altmann,1974) (Table1).

\section{Insert Table 1 here}

\subsection{Cortisol analysis}


Once the amniotic sac was visible, a blood sample was taken from the jugular vein into heparinized plain tubes $(5 \mathrm{~mL})$. Samples were centrifuged at 3,000 rpm for $15 \mathrm{~min}$ at $4^{\circ} \mathrm{C}$, and stored at $-20^{\circ} \mathrm{C}$ until hormonal analysis. The concentration of cortisol was determined by enzyme immunoassay using an "in home-kit" (validated by Chacón et al., 2004). Each sample was determined in duplicate from $50 \mu$ of plasma. The mean of the duplicate was used as the result and expressed in $\mu \mathrm{g} / \mathrm{ml}$. Inter- and intra-assay coefficients of variation were 3.5-6.0\% and 3.9-9.9\%, respectively.

\subsection{Remedying the mother-young relationship}

\subsubsection{Confinement of mothers rejecting their calves}

To ensure adoption of abandoned calves, each dam showing mismothering behaviour was isolated with her neonate in an individual enclosure away from the herd and restrained. Because rejecting she-camels can be quite aggressive (Photos $1 \mathrm{~A}, 1 \mathrm{~B}$ and $1 \mathrm{C})$, we used a multiple procedure to prevent any injury to the young and consisting of:

- Restraining the mother with a $1.5 \mathrm{~m}$ of a strong rope in her front leg.

- Using a muzzle mouth guard on the mother to prevent her from biting the newborn and take it off only in her feeding times. At this time, a qualified person surveyed the mother to prevent her from attacking the newborn when approached.

- Tying the mother's front and back legs together with a $1 \mathrm{~m}$ rope to prevent her from kicking the newborn.

- Hanging up a thin rope onto the hoofs of the mother once she expressed aggression, and removing it when she showed some nursing behaviour. 
- Encouraging the calf to suckle at the udder.

- Providing an extra amount of concentrate food whenever nursing behaviour was observed.

\subsubsection{Oxytocin treatment, milking and newborn feeding}

Once the mother was moved into the confinement enclosure, $5 \mathrm{IU}$ of synthetic oxytocin (Biocytocine, Laboratoires Biové, Arques, France) were injected into the jugular vein. A qualified person collected an amount of $300 \mathrm{ml}$ of colostrum from the dam and ensured her newborn was fed using a baby bottle held on the surface of the udder and keeping the body contact between the two animals (Photo 1D). This intervention was repeated three times per day $(8: 00,12: 00$ and 16:00) until the mother stopped being aggressive and accepted her neonate.

\subsection{Statistical analyses}

Boris software 6.3.1 (Friard and Gamba, 2016) was used to analyze behavioural data. Statistical analyses were performed with GraphPad Prism 7.00 for Windows (2016). Test of normality (Shapiro-Wilk test) was performed and showed a non-normal distribution. Consequently, comparison between the two mothers group on maternal expression during calving (change in birth site, head-turning, changing posture, tail raising, posture during newborn expulsion and newborn attack), and maternal behaviours (sniffing duration and number and low and high-pitched grunts) during the $1^{\text {st }}$ hour and the $7^{\text {th }}$ day postpartum were performed using the MannWhitney test. Overall, the effect of time $(1 \mathrm{~h}, 6 \mathrm{~h}, 12 \mathrm{~h}, 24 \mathrm{~h}, 48 \mathrm{~h}, 72 \mathrm{~h}$ of confinement and $7 \mathrm{~d}$ postpartum) on maternal behaviors was performed by KruskalWallis test with Dunn's correction for multiple comparisons. $P$-values less than 0.05 
were considered as statistically significant. Results are presented in terms of median and lower and upper quartiles [LQ-HQ].

The unpaired $t$ test was used to compare plasma cortisol levels during parturition between accepting and rejecting mothers. Results are presented as means \pm standard errors (SEM) and $P$-values less than 0.05 were considered as statistically significant.

\section{Results}

\subsection{Calving behaviour and cortisol levels in mothers accepting or rejecting their} newborns

\subsubsection{Calving behaviours}

The proportion of females rejecting their newborns was $5 / 36$ during the $1^{\text {st }}$ and $1 / 9$ females for the $2^{\text {nd }}$ calving seasons, representing $13.3 \%$ of the herd. The duration of parturition was longer in the mothers rejecting their calves compared to those accepting them (Mann-Whitney $U=7 ; P=0.04$ ). Compared to the accepting mothers, those which rejected their neonates spent more time in standing position during calving (Mann-Whitney $U=4 ; P=0.01$ ), but there was no significant differences in the time spent lying (Fig. 1).

During parturition, mothers rejecting their calves changed their birth place (Mann-Whitney $U=1 ; P=0.003$ ) and turned the head towards their abdomen more frequently (Mann-Whitney $U=3 ; P=0.007$ ) than those accepting their calves. There was no difference between the two groups in changing posture and tail raising behaviour (Fig. 1). Five out six rejecting females adopted the standing position during 
the expulsion process and two kicked strongly backwards with their hind legs while this behaviour was never observed in mothers accepting their neonates.

\section{Insert Fig. 1 here}

\subsubsection{Plasma cortisol level}

Mothers abandoning their newborns had higher plasma concentrations of cortisol at parturition than those accepting their newborns $(47.7 \pm 2.0$ vs. $29.5 \pm 3.0$ $\mathrm{ng} / \mathrm{ml}$; respectively, $P<0.01)$.

\subsubsection{Causes of newborn rejection}

In our study, the main reasons for abandonment were problems during parturition and the presence of an alien calf (Table 2). The main cause of rejection was found in the birth process (three occurrences). Two females had a long duration of parturition compared to normal calving associated with more discomfort and pain, suggesting dystocia. The third case of mother rejection was associated with dystocia and uterine prolapse in which the uterus protrudes out of the vagina. It required the intervention of the institutional veterinarian who replaced the uterus into its normal position and provided appropriate medical treatment. Only one rejection event was observed in the presence of an alien calf in the calving pen, in which the she-camel displayed maternal response prior to parturition and adopted the alien calf, which lead the mother to reject her own neonate. We hypothesize that the presence of the alien calf is the responsible of this mismothering case. The last case concerned a repeated rejecter, a female that never accepted her newborn in eight successive parturitions. No particular sign of complication during calving was witnessed in this dam. 


\section{Insert Table 2 here}

\subsection{Maternal behaviour}

\subsubsection{Behaviour during the first hour postpartum}

Just after giving birth, the accepting mothers stayed close to their neonates and provided care by protecting them between their front legs. During the first hour postpartum, mothers rejecting their neonates exhibited less sniffing (both duration and number), emitted less low and high-pitched grunts than those accepting their neonates, and failed to show proper maternal care (Table 3). In addition, they were indifferent to and moved away from their progeny. The mother who suffered from dystocia and uterus prolapse was unable to get up and remained near her calf without any responsiveness.

\section{Insert Table 3 here}

\subsubsection{Behavioural progress in mothers rejecting newborns}

In the confinement enclosure, the calves approached to suckle their mothers, but they displayed attack behaviours in response and refused to nurse (Photos 1A, $1 \mathrm{~B}$ and $1 \mathrm{C})$. The number of these behaviours was the highest in the first $6 \mathrm{~h}$ before declining significantly (Kruskal-Wallis $=32.4 ; P<0.0001)$ after one day and disappearing almost completely after 3 days of confinement (Fig. 2A). The reverse is observed in the sniffing activity, which was limited in the first day. Then, both the duration (Kruskal-Wallis $=21.7 ; P=0.001 ;$ Fig. $2 \mathrm{~B}$ ) and the number of sniffing bouts (Kruskal-Wallis $=22.0 ; \mathrm{P}=0.001 ;$ Fig. $2 \mathrm{C}$ ) increased significantly in the following days.

The number of high-pitched grunt was high during the first hour of confinement, dropped after 12 hours and then remained at a low level (Kruskal-Wallis $=29.4 ; P<$ 
0.0001; Fig. 3A). By contrast, the number of low-pitched grunt started low (KruskalWallis $=21.4 ; P=0.001 ;$ Fig. $3 \mathrm{~B}$ ) and increased progressively over the first 3 days of confinement before declining significantly on the $7^{\text {th }}$ day.

\section{Insert Figures $\mathbf{2}$ and $\mathbf{3}$ here}

Progressively, mothers accepted the presence of their newborns without any aggressive reactions. The next step was acceptance of the calf's attempts to make body contact without paying any particular attention to it or exhibiting any maternal care. This was facilitated by the human positioning the calf into normal suckling posture when giving colostrum and milk through a bottle (Photo 1D and 1E). The final step was total acceptance of the rejected calf with remediation of the mother-young relationship and complete restoration of maternal behaviour (Photos 1F and 1G).

\section{Insert Photos 1 here}

\subsubsection{Maternal behavioural in mothers accepting and rejecting newborns at the $7^{\text {th }}$} day postpartum

After returning to the herd, and at day 7 postpartum rejecting mothers exhibited more low-pitched grunts (Mann-Whitney $U=0 ; P=0.001$ ) and sniffing bouts (MannWhitney $\mathrm{U}=2 ; P=0.005$ ) compared to the accepting mothers. However, there was no difference in the high-pitched grunts $(P=0.45)$ and in sniffing duration $(P=0.13)$ between the two mother's group (Fig. 4).

\section{Insert Figure 4 here}

\section{Discussion}

Newborn camel rejection by mothers had never been described before the present work. Despite the limited sample size, and the luck of comparison with other 
methods to remediate mismothering, this study provides an applied technique to reduce mismothering and to remediate this problem of rejection in the camel.

Aberrant maternal behaviour was related to birth difficulties with dystocia and uterine prolapse in three cases, rejection of the neonate in two occurrences, while acceptance of an alien calf prior to giving birth was observed only once. It is a phenomenon that should not be neglected since it affected $13 \%$ of the herd. This aberrant behaviour is reversible and mothers needed 3 days of restrain and human assistance to maintain contact with the calf and restore signs of acceptance. One striking element is that mismothering was displayed by multiparous camels, while in domestic ungulates such behaviour characterizes inexperienced primiparous mothers (Dweyer and Smith, 2008; McDonnell, 2012; Lv et al., 2015).Ihuthia (2010) reported rather frequent newborn abandon by multiparous camels. He reported that up to $27.5 \%$ of abandon cases were registered in experienced camels. Some mares, almost always primiparous, react to their neonate with fear behavior as they react to objects which they have not been exposed. Positive reinforcement is effective in helping a horse overcome fear of her newborn (McDonnell, 2012). In sheep and horses, there is some speculation that in addition to environmental factors, maternal rejection might also have a genetic background and may make an animal more likely to reject the offspring repeatedly (Juarbe-Diaz et al., 1998; Grandinson, 2005). However, hormonal failure during post-partum could also explain repeated calf rejection in our camels. In fact, it has been reported that in ewes, females with better maternal behavior have a higher level of oxytocin and noradrenaline than mismothering ones (Wang et al., 2021).

In our study, the duration of parturition was longer in dromedary females that rejected their calves compared to those accepting them. That parturition is a source of 
discomfort is unquestionable and maybe even more in mammals giving birth to a reduced number of newborns, especially singletons because of their size. Parturient cows become quite agitated immediately before parturition, and in sheep the incidence of prolonged and difficult parturition is threefold higher in single-bearing ewes (Grommer et al., 1985; Von Keyserlingk and Weary, 2007). This can impair the mother's motivation to care for her offspring (Nowak et al., 2000). Prolonged and difficult parturition, assigned to pain and discomfort, is associated with reduced mothering behaviour in ewes and mares, and contributes to increase newborn rejection (Dwyer et al., 2003; Żurek and Danek, 2012).

Three typical signs of uneasiness were observed in camels: head-turning towards the abdomen, regular changes of birth site, and standing position. Close to parturition, females start to behave unusually, and restlessness is part of it. In some species like cattle, restlessness is associated with frequent orientation of the head towards the abdomen and reflects imminent calving (Barrier et al., 2012). It is considered as a sign of disturbance since this behaviour is observed more frequently in mothers needing assistance (Mainau et al., 2010). In this regard, camels are very similar to cattle. Isolation seeking and selecting a birth site is another general trend in domestic ungulates (Jensen, 2017), a behaviour that cannot be achieved under intensive conditions. The constraints imposed on stabled camels may disturb the future mother in her choice of birthplace, prolong labor, and impair the behavioural changes necessary for the onset of maternal motivation as already described in stabled animals (Grandinson, 2005; Nowak and Poindron, 2006). It has been shown in sheep reared under intensive conditions, that should cubicles be provided for isolation, periparturient ewes use them actively, and when doing so they spend less time moving around and are less likely to be separated from their lambs (Gonyou and 
Stookey, 1985). In our experiment, she-camels that displayed mismothering changed birth site more frequently than those that accepted their calves. Likewise, studies in sheep have shown that twin-bearing ewes are more likely to desert one of their lambs if they have been moved away from the birth site (Nowak, 1996). Selecting and staying on the birth site is crucial for the development of mother-young interaction and bonding. Adequate space and facilities with minimal provocation of protective behavior are recommended until protectiveness period naturally diminish.

Restlessness was also associated in she-camels with more frequent standing posture during the expulsion process, and sometimes kicking. This reflects intense discomfort as reported in cows (Norman and Youngquist, 2016) or in primiparous she-camels (Hammadi et al., 2021). In addition, rejecting mothers preferred the standing position during calving, which is not the normal posture adopted by dromedary camels as documented recently by Hammadi et al. (2021). Lateral recumbency is in fact a general trend in domestic ungulates. Whether birth difficulties were directly responsible for increased locomotion and aberrant postures or due to the emotional reactivity of some females that were stressed by the indoor rearing conditions is unknown and should deserve further attention.

In any case, plasma cortisol concentration was shown to be higher in shecamels that expressed mismothering. In ungulates, cortisol levels typically increase with labor and rise during expulsion of the fetus (Nagel et al., 2019). Agarwal et al. (1992) reported a periparturient concentration around $25-30 \mathrm{ng} / \mathrm{ml}$ in camels which is considered to be important. While high concentrations around calving may arise from the need for glucocorticoids increased to induce lactation, the metabolic clearance rate reduced by estrogens and the onset of parturition trigged by fetal 
maturation, abnormal parturition exacerbates such response (Sathya et al., 2007).

Our results confirmed these findings and show that cortisol, birth difficulties and mismothering were related.

Under overcrowded conditions, stealing other neonates is common in domestic ungulates and has deleterious consequences with mothers accepting alien young but rejecting their own (Owens and Edey, 1985). It is particularly the case when two females give birth at the same time because the amniotic fluids are attractive around birth, determine the choice of birth site once spilt on the ground, and trigger maternal licking (Nowak and Poindron, 2006; Poindron et al., 2007). This was observed only once in our she-camels. We cannot conclude whether the scarcity of such behaviour was due to the fact that camels, unlike other ruminants, do not lick their young after giving birth (Hammadi et al., 2021) or because calving was scattered over several months, making stealing of newborns unlikely to happen.

In Maghrebi dromedary camels, an intense period of behavioural interactions between the mother and her newborn usually takes place after birth during which sniffing and low-pitched grunt characterize maternal responsiveness (Hammadi et al., 2021). It is believed that such behaviours are important for promoting bond formation between the mother and her newborn like in sheep and goats (Grandinson, 2005; Nowak and Poindron, 2006; Poindron et al. 2007). During the first postpartum hour, she-camels displaying birth difficulties failed to show proper maternal care and rejected their young. Unlike those that accepted their neonates, mothers attacked and bit their own if they approached to suckle, hardly smelt them, and emitted highpitched grunt. Newborn rejection is also observed in horses but with a different reaction comparatively to camels, in which mares going to their newborns and attack, 
squeal, bite, and kick them, leading to injuring them (Zurek and Danek, 2012).

Rejection behaviours in other ungulates like sheep are less severe with head threatening, butting and pushing. Care must be taken in camels to protect the calf by restraining the mother's movement as bites and kicks might be fatal. Calf rejection must be dealt with immediately after being witnessed to have the best chance of solving the issue.

In the present work, the first step to remedy mismothering was to isolate the mother and her abandoned calf in a small yard. The second was to restrain agitation by putting a muzzle on the mother's nose and tying up her legs. Biting and kicking were prevented while the female could still walk around freely. The third stage was to provide colostrum to the calf by milking the mother after an intravenous injection of oxytocin and bottle-feeding the neonate. Finally, human assistance helped the calf to find the teats, maintain contact with the mother, and suckle without being rejected. All these steps were performed by a qualified person who provoked proximal interindividual interactions. By doing so, aggressive behaviours and high-pitched grunt vanished after 2 days of confinement while sniffing and low-pitched grunt were restored. The she-camel began to accept the newborn showing that the motheryoung relationship became satisfactory, and that in all likelihood a bonding process was taking place.

The mechanisms restoring maternal acceptance are unknown but our methods combined two main factors. The first is the use of restraint, a method known to induce fostering in sheep (Alexander and Bradley, 1985) since it prevents aggression, promotes close contact, and facilitates nursing. Proximal contact facilitates perception of body odors, and olfactory communication is crucial for the 
establishment of a bond between mother and offspring in sheep and goats (Nowak and Poindron, 2006; Poindron et al., 2006). Restoring maternal responsiveness with the use of restraint takes several days in sheep and only two days in horses (JuarbeDiaz et al., 1998). Camels fit within that timeframe. The second factor could be oxytocin. Oxytocin has been shown to induce maternal behaviour in a number of mammals including ruminants (Kendrick, 2000). It stimulates physical proximity between the mother and young, minimizes rejection of newborns and facilitate nursing (Keverne and Kendrick, 1992). Oxytocin has also been found to reduce aggression towards offspring and to decrease the level of fearfulness. The injection of exogenous Biocytocine ${ }^{\circledR}$ prior to milking, milking itself and nursing - which are known to trigger the release of central oxytocin - might have facilitated the onset of maternal responsiveness in rejecting she-camels.

\section{Conclusion}

In conclusion, breeders of stabled dromedary camels should be able to deal with mismothering immediately after calving. Reserving a special calving pen may be essential for each periparturient mother to avoid newborn rejection and calf stealing by alien females. An isolated confinement enclosure is necessary to remediate the mother-young relationship and encourage maternal care. Our study showed that dromedary females that rejected their newborns needed 3 days of restrain and human assistance to accept their calves correctly. This work describes some aspects relating to abnormal maternal behaviour but does not cover all of the issues. There are still many aspects to be clarified. One striking element is that mismothering was displayed by multiparous camels, while in domestic ungulates such behaviour characterizes inexperienced primiparous mothers. In sheep and horses, there is 
some speculation that in addition to environmental factors, maternal rejection might also have a genetic background and may make an animal more likely to reject the offspring (Juarbe-Diaz et al., 1998; Grandinson, 2005). The factors involved in this phenomenon are yet to be identified. No doubt there is great scope for future research in maternal behaviour in the camel.

\section{Declaration of interest}

The authors declare that they have no conflicts of interest.

\section{Acknowledgements}

The present work was carried out in the "Laboratoire d'Elevage et Faune Sauvage (LR16IRA04) at the Institut des Régions Arides de Médenine". It was funded by the Ministère de l'Enseignement Supérieur et de la Recherche Scientifique. Our gratitude to the farm staff of the "Laboratoire d'Elevage et Faune Sauvage" for their care of the animals and their invaluable assistance. The authors would like also to express their deep appreciation to the staff of the "Faculty of Veterinary Medicine University of Zaragoza, Spain" for their help in the cortisol analyses.

\section{Ethics statement}

The experimental conditions of the present work complied with the European Directive 2010/63/EU on the protection of animals used for scientific purposes.

\section{References}

Abd-El-Rahman, H.M.A., Ibrahim, M.A., Elmetwaly, H.A., 2017. Hormonal profile, antioxidant status and some biochemical parameters during pregnancy and periparturient period in dromedary she camel. Egypt. J. Vet. Sci. 48, 81-94. 
Agarwal, S.P., Rai, A.K., Khanna, N.D., 1992. Studies on postpartum female camels and their neonates. Proc. 1st Int. camel Conf. $2^{\text {nd }}$ to $6^{\text {th }}$ Feb. 1992. Dubai. Ed. Allen W.R., Higgins A.J., Maybew I.G., Snow D.H. and Wade J.F. 143-148.

Alexander, G., Bradley, L.R., 1985. Fostering in sheep. IV. Use of restraint Appl. Anim. Behav. Sci. 14, 355-364.

Altmann, J., 1874. Observational study of behavior: sampling methods. Behaviour. 49, 227-267.

Barrier, A.C., Ruelle, E., Haskell, M.J., Dwyer, C.M., 2012. Effect of difficult calving on the vigour of the calf, the onset of maternal behaviour, and some behavioural indicators of pain in the dam. Prev. Vet. Med. 103, 248-256.

Challis, J.R.G. and Brooks, A.N., 1989. Maturation and activation ofhypothalamicpituitary-adrenal function in fetal sheep, Endocrine Reviews, 10, 182-204.

Chniter, M., Salhi, I., Harrabi, H., Khorchani, T., Lainé, A-L., Nowak, R., Hammadi, M., 2016. Physiological changes in the peri-partum period and colostral lgG transfer in prolific D'man sheep: effects of parity and litter size. Trop. Anim. Health. Prod. 48, 387-394.

Deiss, V., Temple, D., Ligout, S., Racine, C., Bouix, J., Terlouw, C., Boissy, A., 2009. Can emotional reactivity predict stress responses at slaughter in sheep? Appl. Anim. Behav. Sci. 119, 193-202.

Dioli, M., 2012. The Traditional Management of the One-Humped Camel in the Horn of Africa: Milking, Fostering and Weaning Techniques. In: Camels in Asia and North Africa. Interdisciplinary Perspectives on their Past and Present 
Significance Chapter: IV- Dromedaries (Camelus dromedarius) Publisher: Österreichische Akademie der Wissenschaften Wien Editors: Eva-Maria Knoll, Pamela Burger.

Dwyer, C., Lawrence, A., Bishop, S., Lewis, M., 2003. Ewe-lamb bonding behaviours at birth are affected by maternal under nutrition in pregnancy. $\mathrm{Br}$. J. Nutr. 89, 123-136.

Dwyer, C.M and Lawrence, A.B., 2005. A review of the behavioural and physiological adaptations of hill and lowland breeds of sheep that favour lamb survival. Appl. Anim. Behav. Sci. 92, 235-260.

Faye, B., 2016. The camel, new challenges for a sustainable development. Trop. Anim. Health. Prod. 48, 689-692.

Friard, O., Gamba, M., 2016. BORIS: a free, versatile open-source event-logging software for video/audio coding and live observations. Methods in Ecology and Evolution 7, 1325-1330.

Gonyou, H.W., Stookey, J.M., 1985. Behavior of parturient ewes in group-lambing pens with and without cubicles. Appl. Anim. Behav. Sci. 14, 163-171.

Grandinson, K., 2005. Genetic background of maternal behaviour and its relation to offspring survival. Livest. Prod. Sci. 93, 43-50.

GraphPad Prism, 2016. Prism 7 for Windows version 7.00. GraphPad Prism Software Inc. USA.

Hammadi, I., Chniter, M., Atigui, M., Brahmi, M., Seddik, M.M., B. Salem, W., Lévy, F., Nowak, R., Hammadi, M., 2021. Dam parity and calf sex affect 
maternal and neonatal behaviors during the first week postpartum in stabled Maghrebi dairy camels. Animal. 1-8.

Jensen, P. 2017. The Ethology of Domestic Animals. $3^{\text {rd }}$ Edition. An Introductory Text. CABI. Wallingford, Oxford Shire, UK. 299 pp.

Juarbe-Diaz, S.V., Houpt, K.A., Kusunose, R., 1998. Prevalence and characteristics of foal rejection in Arabian mares. Equine Vet. J. 30, 424-428.

Kendrick, K. M. 2000. Oxytocin, motherhood and bonding. Exp. Physiol. 85, 111124.

Kohari, D., Takakura, A., 2017. Questionnaire investigation to clarify the occurrence rate and characteristics of maternal rejection behavior in Japanese black cattle (Bos taurus). Anim. Sci. J. 88, 2071-2076.

Liggins, C.G., 1994. The role of cortisol in preparing the fetus for birth. Reprod. Fertil. Dev. 6, 141-150.

Mainau, E., Ruiz-de-la-Torre, J. L., Manteca, X., 2010. Effect of time and parity on the behaviour of dairy cows during the puerperal period. Proc. of the $44^{\text {th }}$ ISAE conference, Uppsala, Sweden, 46.

Mohamed, H.E., 2006. Factors affecting cortisol status in camels (Camelus Dromedarius). J. Anim. Vet. Adv. 5, 307-309.

Nagel, C., Aurich, C., Aurich, J., 2019. Stress effects on the regulation of parturition in different domestic animal species. Anim. Reprod. Sci. 207, 153161. 
Norman, S., Youngquist, R.S., 2016. Parturition and Dystocia. Veterian Key: https://veteriankey.com/parturition-and-dystocia-3/.

Nowak, R., 1996. Neonatal survival: Contributions from behavioural studies in sheep. Appl. Anim. Behav. Sci. 49, 61-72.

Nowak, R., Poindron, P., 2006. From birth to colostrum: early steps leading to lamb survival. Reprod. Nutr. Dev. 46, 431-46.

Nowak, R., Porter, R.H., Lévy, F., Orgeur, P., Schaal, B., 2000. Role of motheryoung interactions in the survival of offspring in domestic mammals. Rev. Reprod. 5, 153-163.

Owens, J.L., Edey, T.N., 1985. Parturient behaviour and calf survival in a herd selected for twinning. Appl. Anim. Behav. Sci. 13, 321-333.

Padalino, B., Aubé, L., Fatnassi, M., Monaco, D., Khorchani, T., Hammadi, M., Lacalandra, G. M., 2014. Could Dromedary Camels Develop Stereotypy? The first description of stereotypical behaviour in housed male dromedary camels and how it is affected by different management systems. PLOS One 9, 1-7.

Poindron, P., Lévy, F., Keller, M., 2007. Maternal responsiveness and maternal selectivity in domestic sheep and goats: the two facets of maternal attachment. Dev. Psychobiol. 49, 54-70.

Rørvang, M.V., Nielsen, B.L., Herskin, M.S., Jensen, M.B., 2018. Pre-partum maternal behavior of domesticated cattle: A comparison with managed, feral, and wild ungulates. Front. vet. sci. 5: 45.

Salhi, I., Bessalah, S., Ben Mbarek, S., Chniter, M., Seddik, M.M., Khorchani, T., Hammadi, M., 2014. Passive transfer of maternal immunity in the dromedary 
(Camelus dromedarius), involvement of heavy chain antibodies. Trop. Anim. Health. Prod. 47, 613-618.

Sathya, A., Prabhakar, S., Sangha, S.P.S., Ghuman S.P.S., 2007. Vitamin E and selenium supplementation reduces plasma cortisol and oxidative stress in dystocia-affected buffaloes. Vet. Res. Commun. 31, 809-818.

Vogels, Z., Chuck, G.M., Morton, J.M., 2013. Failure of transfer of passive immunity and agammaglobulinaemia in calves in south-west Victorian dairy herds: prevalence and risk factors. Aust. Vet. J. 91, 150-158.

Von Keyserlingk, M. A.G., Weary, D.M., 2007. Maternal behavior in cattle. Horm. Behav. 52, 106-113.

Żurek, U., Danek, J., 2012. Foal rejection - characteristics and therapy of inadequate maternal behaviour in mares. Ann. Anim. Sci. 12, 141-149. (1)

3
a 65 66 67 68 69 
Fig. 1. Parturition, lying and standing duration (A), number of changing posture, changing place; head turning towards abdomen and tail raising (B) during the calving process in dromedary mothers accepting (accepting group) and rejecting (rejecting group) their calves. Data are expressed as medians and 1st and 3rd quartiles. a-b: for each parameter, difference between groups is significant at $P=0.05$.

Fig. 2. Evolution of newborn, number of attack (A), and duration $(B)$ and number $(C)$ of sniffing in dromedary females that rejected their calves during the confinement period and at day 7 postpartum. Data are expressed as medians and $1^{\text {st }}$ and $3^{\text {rd }}$ quartiles. a-b-c: $P<0.05$.

Fig. 3. Evolution of number of high $(A)$ and low-pitched grunts $(B)$ in the rejecting group during the confinement period and at day 7 postpartum. Data are expressed as medians and $1^{\text {st }}$ and $3^{\text {rd }}$ quartiles. $a-b: P<0.05$.

Fig. 4. Difference between the accepting and rejecting groups in low-pitched grunt (A), high-pitched grunt (B), number of sniffing (C) and sniffing duration (D) at day 7 postpartum. Data are expressed as medians and $1^{\text {st }}$ and $3^{\text {rd }}$ quartiles. a-b: for each parameter, difference between groups is significant at $P=0.05$. 
Fig. 1.

595
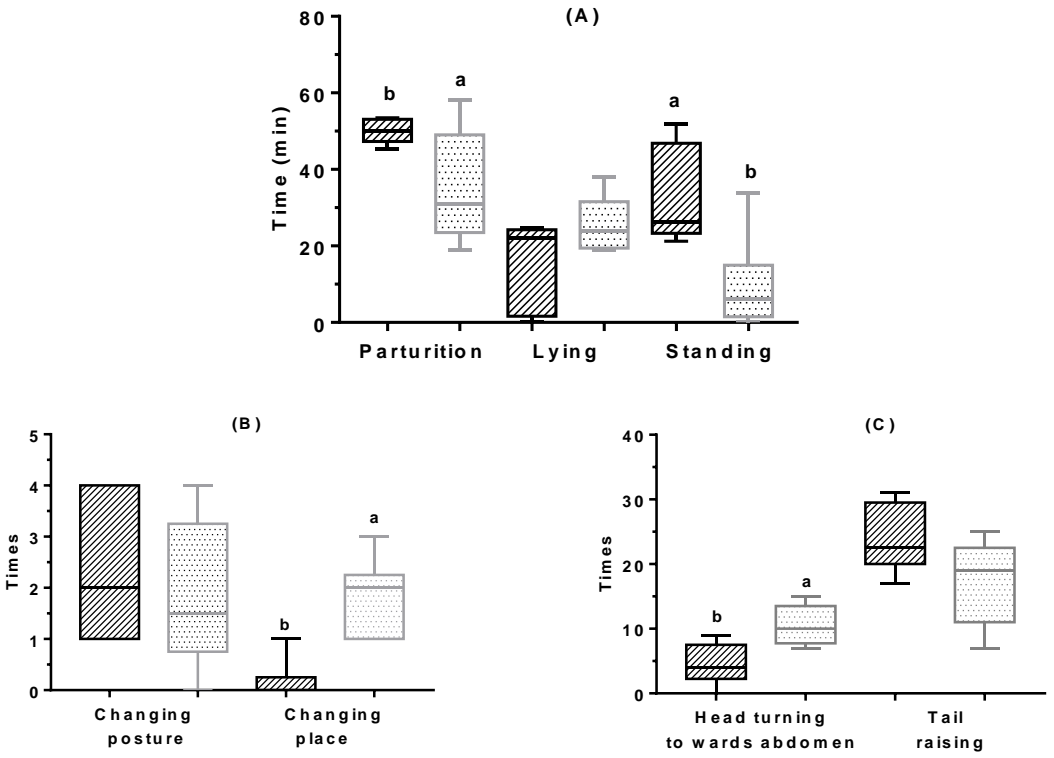

596

: Accepting group

: Rejecting group

597

598

599

600

601

602

603

604

605

606 
Fig. 2.
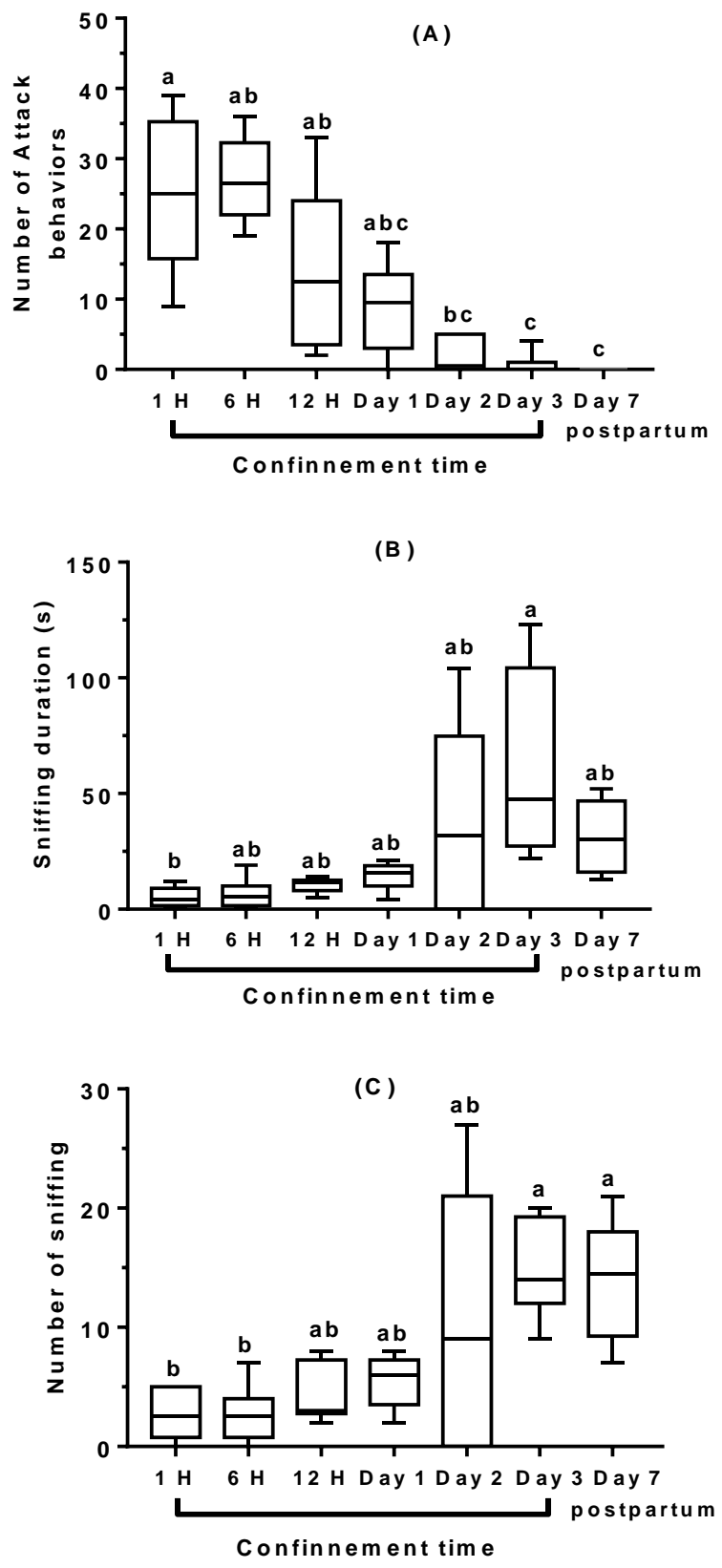
Fig. 3.
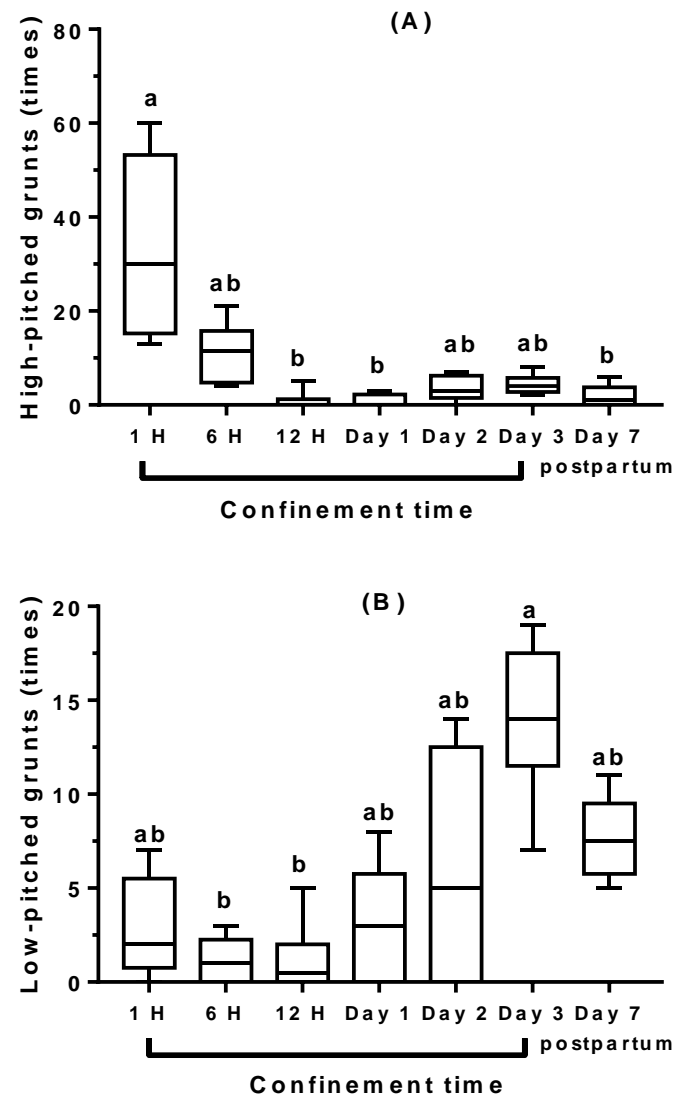
Fig. 4.
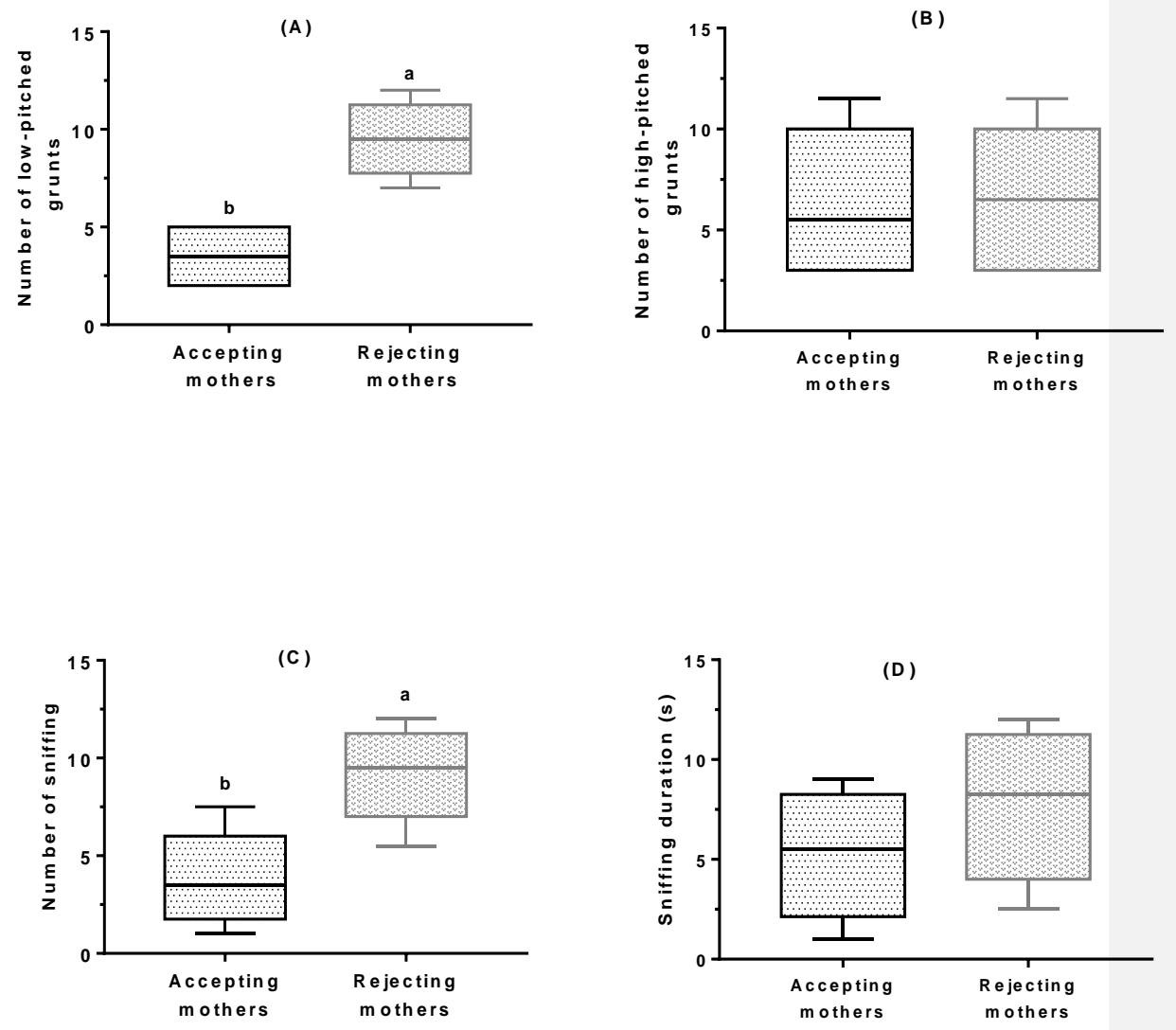


\section{Table 1}

Ethogram of calving and maternal behaviour in Maghrebi dromedary camels

631 (adopted with some modifications from Hammadi et al., 2021).

\begin{tabular}{|c|c|c|}
\hline Variable & State/ Event & Definition \\
\hline \multicolumn{3}{|c|}{$\begin{array}{l}\text { Behaviors during parturition } \\
\text { (second stage) }\end{array}$} \\
\hline Parturition & Duration & $\begin{array}{l}\text { Duration (min) of the birth } \\
\text { process (second stage): from } \\
\text { appearance of the amniotic sac to } \\
\text { total expulsion of fetus. }\end{array}$ \\
\hline Lying position & Duration & $\begin{array}{l}\text { Duration (min) during which the } \\
\text { female lies on the ground. }\end{array}$ \\
\hline Standing position & Duration & $\begin{array}{l}\text { Duration (min) during which the } \\
\text { female stands upright on all four } \\
\text { legs. }\end{array}$ \\
\hline Changing posture & Event & $\begin{array}{l}\text { Switching from lying to standing } \\
\text { positions or vice versa. }\end{array}$ \\
\hline Changing place & Event & $\begin{array}{l}\text { Female changes birth site from } \\
\text { one place }\left(17.5 \mathrm{~m}^{2}\right) \text { to another } \\
\text { during parturition. }\end{array}$ \\
\hline Number of tail raising & Event & $\begin{array}{l}\text { Number of up and down tail } \\
\text { movements away from the body. }\end{array}$ \\
\hline
\end{tabular}




\begin{tabular}{|c|c|c|}
\hline $\begin{array}{l}\text { Head-turning towards } \\
\text { abdomen }\end{array}$ & Event & $\begin{array}{l}\text { Head lifted and oriented towards } \\
\text { the abdomen with stretched neck. }\end{array}$ \\
\hline Kicking & Event & $\begin{array}{l}\text { Mother kicks with her hind legs } \\
\text { during expulsion. }\end{array}$ \\
\hline Position during expulsion & Event & $\begin{array}{l}\text { Position adopted by the mother } \\
\text { during the complete phase of } \\
\text { expulsion (lying or standing } \\
\text { position). }\end{array}$ \\
\hline
\end{tabular}

Behaviors after parturition

Moving away from the

Event

Mother moving more than $2 \mathrm{~m}$

newborn

away from her newborn just after

giving birth.

Pain associated with

Event

- Long duration of the first and the

parturition

second stages of parturition

(Hammadi et al., 2021),

- Placenta takes longer than 12

hours to shedding,

- Uterus slips down into or

protrudes out of the vagina,

Attack

Event

Number of aggressive behaviours

(kicking, biting, and head

pushing) displayed by the mother

toward her calf. 
Low-pitched grunt

High-pitched grunt

Sniffing
Event

Event

Event and duration Number and duration (s) of

nose and the newborn. contacts between the mother's

Number of quiet vocalizations

emitted with the mouth closed.

Number of loud calls emitted with

the mouth open.
632

633

634

635

636

637

638

639

640

641

643

644

645

646

647 649

8

642

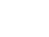
(

\section{6} (1) 1 43 44

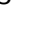
47

\section{8}




\section{Table 2}

Calving date, age, parity, and body condition score (BCS) of mother and the cause of each case of camel calf rejection.

\begin{tabular}{llllll}
\hline $\begin{array}{l}\text { Camels } \\
\text { id }\end{array}$ & Calving date & Age & Parity & $\begin{array}{l}\text { Cause of calf } \\
\text { rejection }\end{array}$ & $\begin{array}{l}\text { Duration of } \\
\text { the } 2^{\text {nd }} \text { stage } \\
\text { of parturition } \\
(\mathbf{m i n})\end{array}$ \\
& & & & & 48 \\
\hline$\# 9810$ & $09 / 10 / 2016$ & 18 & Multipara & Repeated rejecter & 45 \\
$\# 513$ & $28 / 10 / 2016$ & 11 & Multipara & Acceptance of an alien calf & 45 \\
$\# 9606$ & $03 / 01 / 2017$ & 21 & Multipara & Dystocia and uterine & 53 \\
& & & & prolapse & \\
$\# 413$ & $06 / 03 / 2017$ & 13 & Multipara & Dystocia & 52 \\
$\# 913$ & $06 / 03 / 2017$ & 8 & Multipara & Dystocia & 54 \\
$\# 9810$ & $23 / 10 / 2018$ & 20 & Multipara & Repeated rejecter & 48 \\
\hline
\end{tabular}

655 
Table 3

667

Difference between the accepting and rejecting mothers in the expression of maternal behaviours during the first hour postpartum. Data are expressed as medians and $1^{\text {st }}$ and $3^{\text {rd }}$ quartiles.

\begin{tabular}{llll}
\hline Maternal behaviours & Accepting mothers & Rejecting mothers & $P$-value \\
\hline Sniffing duration (s) & $297.5[228.5-669.0]^{\mathrm{a}}$ & $1.5[0.0-3.5]^{\mathrm{b}}$ & 0.002 \\
Number of Sniffing & $73.5[56.2-96.5]^{\mathrm{a}}$ & $0.5[0.0-2.5]^{\mathrm{b}}$ & 0.002 \\
High-pitched grunt & $25.0[17.5-32.0]^{\mathrm{a}}$ & $1.5[0.0-4.25]^{\mathrm{b}}$ & 0.001 \\
Low-pitched grunt & $38.0[32.0-49.5]^{\mathrm{a}}$ & $0.0[0.0-0.0]^{\mathrm{b}}$ & 0.001
\end{tabular}




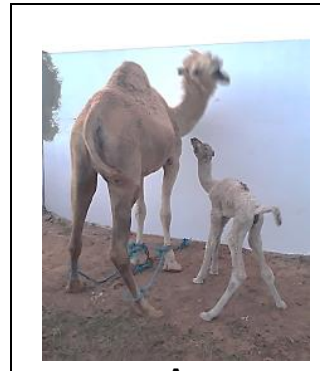

A

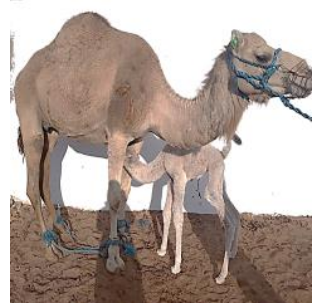

E

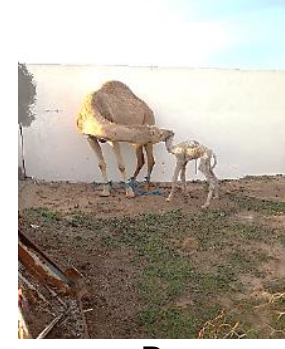

B

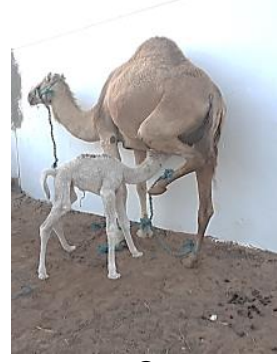

C

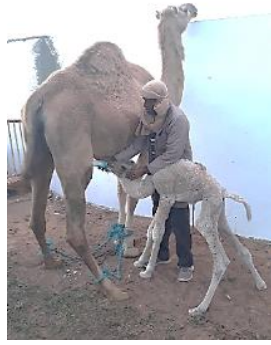

D

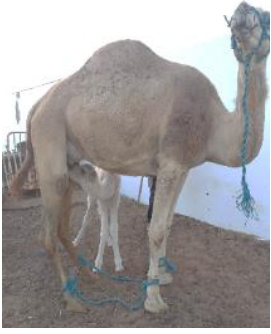

$\mathbf{F}$

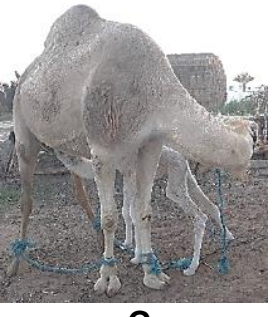

G
679

Photos 1: Steps in calf acceptance during the confinement period in dromedary camels.

A: attacking the calf; B: biting the calf; C: refusing suckling; D: colostrum collection from the mother and Bottle-feeding the calf near to the udder; E: mother accepts body contact; F: suckling acceptance without maternal care; G: suckling process with maternal care (sniffing). 